\title{
PENGETAHUAN IBU HAMIL TENTANG MANFAAT PEMBERIAN ASI EKSKLUSIF
}

\author{
${ }^{1}$ Tazy A. Mashanafi \\ ${ }^{2}$ Eddy Suparman \\ ${ }^{2}$ Hermie M. Tendean
}

\author{
${ }^{1}$ Kandidat Skripsi Fakultas Kedokteran Universitas Sam Ratulangi Manado \\ ${ }^{2}$ Bagian Obstetri Ginekologi Fakultas Kedokteran Universitas Sam Ratulangi Manado \\ Email: tazymashanafi@yahoo.com
}

\begin{abstract}
Breast-feeding means that the baby is not given other food supplements other than breast feeding itself during the age of $0-6$ months old. Breast-feeding is the best and most perfect food for babies since it has rich nutrition contents, therefore, it cannot be substituted by even the most expensive formula milk. This was a a descriptive study with a cross sectional design. The results showed that based on the knowledge about breast-feeding, 16 respondents (32\%) graduated of senior high school had adequate knowledge; all 12 respondents (24\%) graduated of university/college had good knowledge; and all 10 respondents $(20 \%)$ of private enterprises employees had adequate knowledge. Conclusion: In the study, most respondents had adequate knowlede about breast-feeding.
\end{abstract}

Keywords: exclusive breast-feeding.

\begin{abstract}
Abstrak: ASI eksklusif adalah bayi hanya diberikan ASI saja tanpa makanan tambahan lain pada bayi berumur 0-6 bulan. ASI eksklusif adalah makanan terbaik dan paling sempurna untuk bayi dengan kandungan gizi yang tinggi dan tidak bisa tergantikan oleh susu formula termahal sekalipun. Penelitian ini menggunakan metode deskriptif dengan pendekatan potong lintang. Hasil penelitian memperlihatkan bahwa mengenai pengetahuan tentang pemberian Asi eksklusif 16 responden dengan pendidikan SMA (32\%) mempunyai tingkat pengetahuan cukup dan semua responden sebanyak 12 orang (24\%) dengan pendidikan Diploma/Sarjana tidak ada yang mempunyai pengetahuan kurang tentang pemberian ASI eksklusif. Terdapat 10 responden (20\%) dengan pekerjaan wiraswasta mempunyai pengetahuan cukup tentang pemberian ASI eksklusif. Simpulan: Pada studi ini, sebagian besar responden memiliki pengetahuan cukup mengenai pemberian ASI eksklusif.
\end{abstract}

Kata kunci: ASI eksklusif

Kebahagiaan terbesar bagi seorang perempuan adalah ketika tengah hamil, karena itu berarti dia akan segera memiliki buah hati. Untuk buah hati tercinta, seorang ibu pasti akan memberikan segala hal yang terbaik termasuk di dalamnya memberikan ASI eksklusif. ASI eksklusif adalah bayi hanya diberikan ASI saja tanpa makanan tambahan lain pada bayi berumur 0-6 bulan, karena ASI Eksklusif adalah makanan terbaik dan paling sempurna untuk bayi. Dengan kandungan gizi yang tinggi membuat ASI Eksklusif tidak bisa tergantikan oleh susu formula termahal sekalipun, ASI eksklusif juga tidak pernah basi selama masih dalam tempatnya. Komposisi ASI yang sesuai untuk kebutuhan bayi dan mengandung Zat pelindung dengan kandungan terbanyak ada pada kolustrum. Kolustrum adalah ASI yang berwarna kekuningan yang dihasilkan tiga hari pertama setelah bayi lahir. Tidak 
hanya menguntungkan bagi bayi, ASI Eksklusif juga dapat menjadi salah satu penyelamat kondisi keuangan keluarga seiring dengan semakin meningkatnya harga susu formula ditengah krisis global seperti sekarang ini. Banyak penelitian yang membuktikan bahwa ASI merupakan makanan terbaik dan utama bagi bayi, karena didalam ASI terkandung antibodi yang diperlukan bayi untuk melawan penyakit-penyakit yang menyerangnya. Pada dasarnya ASI adalah imunisasi pertama karena ASI mengandung berbagai zat kekebalan antara lain imunoglobin. Bayi yang tidak mendapat ASI beresiko terhadap infeksi saluran pernafasan (seperti batuk, pilek) diare dan alergi. ${ }^{1}$ Menurut hasil Survei Demografi Kesehatan Indonesia (SDKI) tahun 2002-2003 presentase anak di bawah usia 6 bulan yang mendapatkan ASI Eksklusif adalah 39,5\%. ${ }^{2}$ Sedangkan menurut hasil survei Sosial Ekonomi Nasional 2005-2010 cakupan pemberian ASI Eksklusif pada bayi 0-6 bulan tidak ada peningkatan yang signifikan yaitu dari 59,7\% pada 2005 dan 61,5\% pada 2010. ${ }^{3}$ Manfaat ASI Eksklusif memanglah sangat penting baik bagi ibu maupun bayinya. Namun, sangat disayangkan saat ini terlebih di Indonesia, pemberian ASI Eksklusif belum sesuai dengan yang di harapkan. Di Indonesia, rata-rata ibu memberikan ASI Eksklusif hanya 2 bulan. Pada saat yang bersamaan, pemberian susu formula meningkat 3 kali lipat. Data Riset Kesehatan Dasar (RISKESDAS) tahun 2010 menunjukan pemberian ASI di Indonesia saat ini memprihatinkan, presentase bayi yang memperoleh ASI Eksklusif sampai dengan 6 bulan hanya 15,3\%, sedangkan menurut Dirjen Gizi dan KIA masalah utama masih rendahnya penggunaan ASI Eksklusif di Indonesia adalah faktor sosial budaya, kurangnya pengetahuan ibu hamil, keluarga, dan masyarakat tentang manfaat dan pentingnya ASI Eksklusif, serta jajaran kesehatan yang belum sepenuhnya mendukung peningkatan pemberian ASI Eksklusif (PP-ASI). ${ }^{4}$

\section{METODE PENELITIAN}

Penelitian ini menggunakan metode deskriptif dengan pendekatan potong lintang. Penelitian dilakukan di Kecamatan Dumoga Barat, Kabupaten Bolaang Mongondow pada bulan November 2012. Populasi penelitian ialah semua ibu hamil yang ada di Kecamatan Dumoga Barat.

Sampel penelitian sebanyak 50 orang ibu hamil yang ada di Kecamatan Dumoga Barat. Pengumpulan data dilakukan dengan cara menggunakan kuesioner pada ibu hamil.

\section{HASIL PENELITIAN}

Hasil penelitian mencakup tentang analisis univariat yaitu variabel umur, pendidikan, pekerjaan dan pengetahuan sedangkan analisis bivariat yaitu melihat hasil tabulasi silang antara pendidikan dengan pengetahuan dan pekerjaan dengan pengetahuan tentang pemberian ASI eksklusif.

\section{Analisis Univariat}

Tabel 1. Distribusi Responden Menurut Umur Ibu Hamil

\begin{tabular}{ccc}
\hline Umur & $\mathrm{N}$ & $\%$ \\
\hline$<20$ tahun & - & - \\
$20-35$ tahun & 50 & 100 \\
$>35$ tahun & - & - \\
Total & 50 & 100 \\
\hline
\end{tabular}

Tabel 2. Distribusi Responden Menurut Pendidikan Ibu Hamil

\begin{tabular}{ccc}
\hline Pendidikan & $\mathrm{N}$ & $\%$ \\
\hline Diploma/Sarjana & 12 & 24 \\
SMA & 20 & 40 \\
SMP & 18 & 36 \\
Total & 50 & 100 \\
\hline
\end{tabular}

Tabel. 3 Distribusi Responden Menurut Pekerjaan Ibu Hamil

\begin{tabular}{ccc}
\hline Pekerjaan & N & $\%$ \\
\hline Guru & 5 & 10 \\
IRT & 25 & 50 \\
PNS & 7 & 14 \\
Wiraswasta & 13 & 26 \\
Total & 50 & 100 \\
\hline
\end{tabular}


Tabel 4. Distribusi Responden Menurut Pengetahuan Ibu Hamil Tentang Manfaat Pemberian ASI Eksklusif

\begin{tabular}{ccc}
\hline Pengetahuan & $\mathrm{N}$ & $\%$ \\
\hline Baik & - & - \\
Cukup & 28 & 56 \\
Kurang & 22 & 44 \\
Total & 50 & 100 \\
\hline
\end{tabular}

\section{B. Analisis Bivariat}

Tabel 5. Tabulasi Silang Pekerjaan dengan Pengetahuan Manfaat Pemberian ASI Eksklusif

\begin{tabular}{cccccccc}
\hline & & \multicolumn{3}{c}{ Pengetahuan } & \multicolumn{2}{c}{ Total } \\
\cline { 3 - 8 } & & Cukup & $\%$ & Kurang & $\%$ & $\mathrm{n}$ & $\%$ \\
\hline \multirow{4}{*}{ Pekerjaan } & Guru & 5 & 10 & - & - & 5 & 10 \\
& IRT & 6 & 12 & 19 & 38 & 25 & 50 \\
& PNS & 7 & 14 & - & - & 7 & 14 \\
& Swasta & 10 & 20 & 3 & 6 & 13 & 26 \\
\multicolumn{2}{c}{ Total } & 28 & 56 & 22 & 44 & 50 & 100 \\
\hline
\end{tabular}

Tabel 6. Tabulasi silang Pendidikan dengan Pengetahuan Manfaat Pemberian ASI Eksklusif

\begin{tabular}{|c|c|c|c|c|c|c|c|}
\hline & & \multicolumn{4}{|c|}{ Pengetahuan } & \multicolumn{2}{|c|}{ Total } \\
\hline & & Cukup & $\%$ & Kurang & $\%$ & $\mathrm{n}$ & $\%$ \\
\hline \multirow{3}{*}{ Pendidikan } & $\begin{array}{c}\text { Diploma/ } \\
\text { Sarjana }\end{array}$ & 12 & 24 & - & - & 12 & 10 \\
\hline & SMA & 16 & 32 & 4 & 8 & 20 & 50 \\
\hline & SMP & 0 & 0 & 18 & 36 & 18 & 14 \\
\hline \multicolumn{2}{|c|}{ Total } & 28 & 56 & 22 & 44 & 50 & 100 \\
\hline
\end{tabular}

\section{BAHASAN}

Dari Penelitian yang telah dilakukan di Kecamatan Dumoga Barat, Kabupaten Bolaang Mongondow pada november 2012 sampai januari 2013, didapatkan 50 orang ibu hamil sebagai responden. Pada Tabel 1 dijelaskan keseluruhan responden yang berjumlah 50 orang (100\%) tergolongan dalam umur 20-35 tahun.

Pada Tabel 2 dijelaskan karakteristik responden menurut pendidikan, sebagian besar responden terbanyak mempunyai pendidikan SMA dengan jumlah 20 responden (40\%), pendidikan SMP dengan jumlah 18 responden (36\%) dan pendidikan Diploma/Sarjana dengan jumlah 12 responden (24\%). Perlu ditekankan bahwa untuk berhenti menyusui bayinya, meskipun kelompok tahu manfaat seseorang yang berpendidikan rendah tidak berarti mutlak berpengetahuan rendah pula. Peningkatan pengetahuan tidak mutlak diperoleh dari pendidikan formal, akan tetapi juga dapat diperoleh pada pendidikan non formal. ${ }^{15}$

Pada Tabel 3 dijelaskan karakteristik responden menurut pekerjaan, sebagian besar responden terbanyak mempunyai pekerjaan sebagai IRT dengan jumlah 25 responden (50\%), pekerjaan sebagai wiraswasta dengan jumlah 13 responden (26\%), pekerjaan sebagai PNS dengan jumlah 7 responden (14\%) dan pekerjaan sebagai guru dengan jumlah 5 responden (10\%). Pekerjaan seringkali merupakan alasan yang sering digunakan oleh ibu pemberian ASI Eksklusif sehingga perlu lebih ditekankan bahwa walaupun ibu 
bekerja, ibu masih bisa untuk dapat memberikan ASI Ekslusif kepada bayinya (Roesli 2000). ${ }^{15}$

Pada Tabel 4 dijelaskan karakteristik responden menurut pengetahuan manfaat pemberian ASI Eksklusif, sebagian besar pengetahuan cukup dengan jumlah 28 responden (56\%), pengetahuan kurang dengan jumlah 22 responden (44\%) dan pengetahuan baik tidak ada (0\%). Hal ini sejalan dengan pendapat Notoadmodjo (2005) yang mengungkapkan bahwa perilaku yang didasari pengetahuan akan lebih langgeng daripada perilakuny yang tidak didasari pengetahuan. Semakin baik pengetahuan ibu tentang maka seorang ibu akan memberikan ASI Eksklusif kepada bayinya, begitupun sebaliknya. ${ }^{15}$

Pada Tabel 5 dijelaskan hasil tabulasi silang antara pekerjaan dengan pengetahuan responden di Kecamatan Dumoga Barat, Bolaang Mongondow. Responden dengan pekerjaan sebagai guru sebanyak 5 responden (10\%) sudah mempunyai pengetahuan cukup. Responden dengan pekerjaan sebagai IRT dengan total 25 responden (50\%), sedikitnya 6 responden (12\%) sudah berpengetahuan cukup, namun sisanya sebanyak 19 responden (38\%) masih berpengetahuan kurang. Selanjutnya responden dengan pekerjaan PNS sebanyak 7 responden (14\%) keseluruhanya berpengetahuan cukup. Responden dengan pekerjaan swasta dengan total responden 13 responden (26\%), 10 responden (20\%) sudah berpengetahuan cukup namun sisanya sebanyak 3 responden masih berpengetahuan kurang.

Pada Tabel 6 dapat dijelaskan hasil tabulasi silang antara pendidikan dengan pengetahuan responden di Kecamatan Dumoga Barat, Bolaang Mongondow. Responden dengan pendidikan Diploma/ Sarjana sebanyak 12 responden (24\%) keseluruhannya sudah memiliki pengetahuan yang cukup. Responden dengan pendidikan SMA dengan total 20 responden (50\%), 16 responden (32\%) sudah berpengetahuan cukup dan sedikitnya 4 responden (8\%) masih berpengetahuan kurang. Dan terahir responden dengan pendidikan SMP 18 responden (14\%) keseluruhan mempunyai pengetahuan yang masih kurang. Notoatmodjo (2003), menjelaskan bahwa pengetahuan apabila ditunjang oleh pendidikan yang baik maka seseorang dapat mengetahui atau memahami sesuatu yang disampaikan atau diinformasikan, pendidikan juga akan menghasilkan perubahan atau peningkatan pengetahuan masyarakat. ${ }^{16}$

\section{SIMPULAN}

Dari hasil penelitian dan bahasan dapat disimpulkan bahwa seluruh responden termasuk dalam usia yang masih produktif, sebagian besar berpendidikan SMA sudah mempunyai tingkat pengetahuan yang cukup dan semua responden dengan pendidikan Diploma/Sarjana tidak ada yang mempunyai pengetahuan kurang tentang pemberian ASI Eksklusif. Sebagian besar responden dengan pekerjaan wiraswasta sudah mempunyai pengetahuan yang cukup tentang pemberian ASI Eksklusif.

\section{DAFTAR PUSTAKA}

1. Soekirman. Hidup Sehat. Jakarta: Primamedia Pustaka, 2006.

2. Yulfira $\mathbf{M}$, Rachmalina, Manalu $\mathbf{H}$. Pengetahuan, Persepsi, dan Perilaku Ibu tentang Pemberian ASI Eksklusif. 2006. Available from: http://ejournal.litbang.depkes.go.id/in dex.php/MPK/article/view/1122

3. Prita D. Pemberian ASI Eksklusif Di Indonesia Masih Rendah. 2012. Available from: http://www.mediaindonesia.com/med iahidupsehat/index.php/read/2012/08/ 04/5473/5/Pemberian-asi-eksklusifdi-indonesia-masih-rendah

4. Badan Pengembangan Dan Pemberdayaan Sumber Daya Manusia Kesehatan. 2012. Banyak Sekali Manfaat Asi Bagi Bayi dan Ibu. Available from: http://www.bppsdmk.depkes.go.id/in dex.php?option=com_content\&view= article\&id=170:banyak-sekalimanfaat-asi-bagi-bayi-danibu\&catid $=38$ : berita\&item $=82$

5. Elinofia, Doveriyanti R, Roma U. 2012. 
Jurnal e-Clinic (eCl), Volume 3, Nomor 3, September-Desember 2015

Hubungan pendidikan, Pengetahuan, Pekerjaan dan Dukungan Keluarga dengan Pemberian ASI Eksklusif di Puskesmas Sawah Lebar Kota Bengkulu Tahun 2011. Jurnal
Akademi Kesehatam Saota Bakti. Available from: Saptabakti.ac.id.

6. Notoadmodjo S. Ilmu Kesehatan Masyarakat (Prinsip-prinsip Dasar). Jakarta: Rineka Cipta, 2003. 